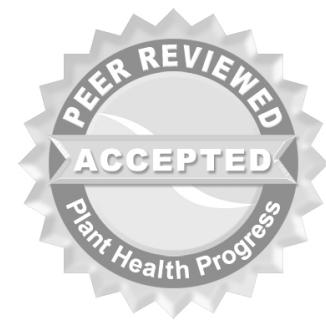

2010. Plant Management Network. This article is in the public domain. Accepted for publication 15 December 2009. Published 17 March 2010.

\title{
Potato Zebra Chip Disease: A Phytopathological
} Tale

J ames M. Crosslin, Research Plant Pathologist, USDA-ARS, Vegetable and Forage Crops Research Unit, 24106 North Bunn Road, Prosser, WA 99350; J oseph E. Munyaneza, Research Entomologist, USDA-ARS, Yakima Agricultural Research Laboratory, 5230 Konnowac Pass Road, Wapato, WA 98951; J udith K. Brown, Professor, School of Plant Sciences, The University of Arizona, Tucson, AZ 85721; and Lia W. Liefting, Plant Pathologist, Plant Health and Environment Laboratory, MAF Biosecurity New Zealand, P.O. Box 2095, Auckland 1140, New Zealand

Corresponding author: James M. Crosslin. jim.crosslin@ars.usda.gov

Crosslin, J. M., Munyaneza, J. E., Brown, J. K., and Liefting, L. W. 2010. Potato zebra chip disease: A phytopathological tale. Online. Plant Health Progress doi: 10.1094/PHP-20100317-01-RV.

\begin{abstract}
Potato zebra chip (ZC) disease is a relative newcomer to the world of important potato diseases. First reported in Mexico in the 1990s, by 2004-2005 the disease was causing serious economic damage in parts of Texas. ZC is now widespread in the south-western and central United States, Mexico, Central America, and was recently reported in New Zealand. By 2006, there seemed to be an association between ZC and the potato psyllid (Bactericera cockerelli). The exact nature of the relationship, however, has only recently been identified by the discovery of a new Candidatus Liberibacter bacterium that is transmitted to potatoes, tomatoes, and other solanaceous hosts by the potato psyllid. This review examines the history of this disease, the association of ZC with the potato psyllid, the host range, and recent research into the bacterial pathogen.
\end{abstract}

\section{Introduction}

In the mid- to late 1990s, potato tubers produced in Mexico when sliced open displayed distinct internal brown discoloration. These tubers subsequently developed unacceptable dark stripes and streaks when processed into potato chips. Foliar symptoms on affected plants included chlorosis, leafrolling, purple discolorations, aerial tubers, and leaf scorch. Due to the characteristic tuber symptoms the name "zebra chip" (ZC) was used to describe the disease and this designation has become well established in the literature. By about 2000, similar symptoms were observed in potatoes grown in the lower Rio Grande valley of Texas. Many growers suffered serious economic losses because the tubers were rejected by processors and entire fields were often abandoned.

In about 2008, tomato plants were observed in California with an unknown disease and a novel bacterium was shown to be associated with the symptomatic plants. The California researchers subsequently detected this new bacterium in diseased potatoes. The bacterium was also found to be associated with the potato psyllid (Bactericera cockerelli). A similar set of circumstances was also reported in New Zealand greenhouse tomato and pepper crops in 2008 (14), and in 2007 in psyllid-infested greenhouse-grown tomatoes in Arizona (2).

This article examines the history of this disease, symptomatology, hosts, distribution, and the recent association of an insect-transmitted bacterium with the ZC disease of potato and diseases of other solanaceous crops in multiple locations worldwide. 
Early Descriptions of the Disease and Start of Research

In the mid 1990s, an apparently new affliction of potatoes was observed in Mexico and parts of Central America (6,11,30). Foliar symptoms resembled those caused by phytoplasmas, including upward rolling of the leaflets, purple or yellow discoloration, aerial tubers, leaf scorch, and early senescence (Figs. 1, 2 , and 3). The fresh tubers showed brown discoloration when cut (Fig. 4). When affected tubers were sliced and fried for potato chips they showed very dark blotches, stripes, or streaks (Fig. 5). Often these streaks coincided with the medullary rays of the tuber. The presence of these characteristic stripes and streaks led to adoption of the common name "zebra chip." By 2000, these symptoms were observed in US potato fields, particularly in the Pearsall and lower Rio Grande valley areas of Texas, and by 2004-2005 the disease was causing significant economic damage in these areas (see $\underline{\mathrm{PDF}}$ from the Center for North American Studies link ).

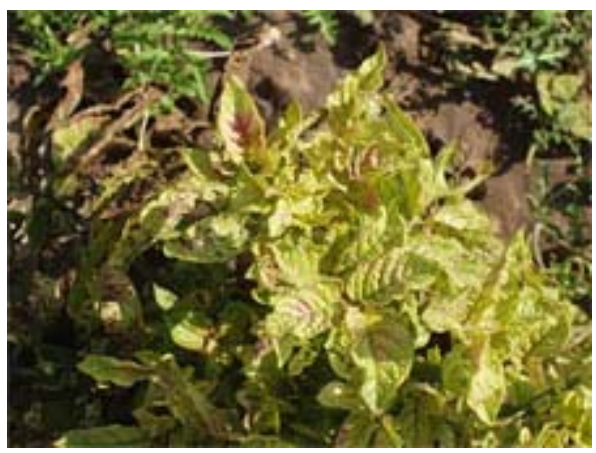

Fig. 1. Chlorosis and purpling of zebra chip plants at a field trial in Weslaco, TX.

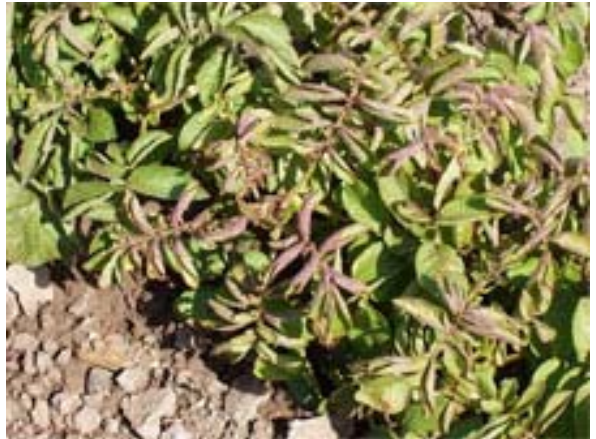

Fig. 2. "Purple top" like symptoms of zebra chip infected plant.

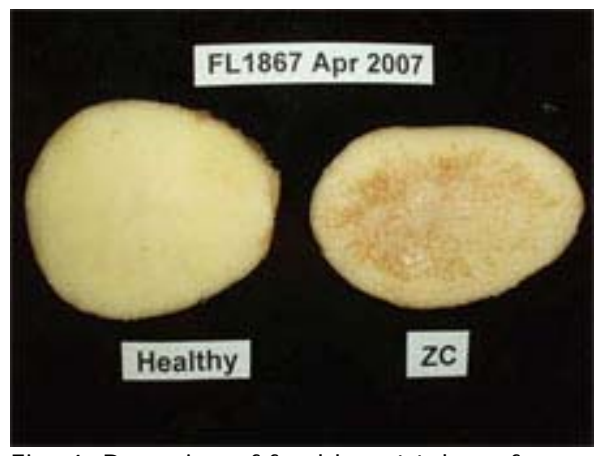

Fig. 4. Browning of freshly cut tuber of cV. FL1867 affected by zebra chip. These tubers were collected from a commercial field in Texas.

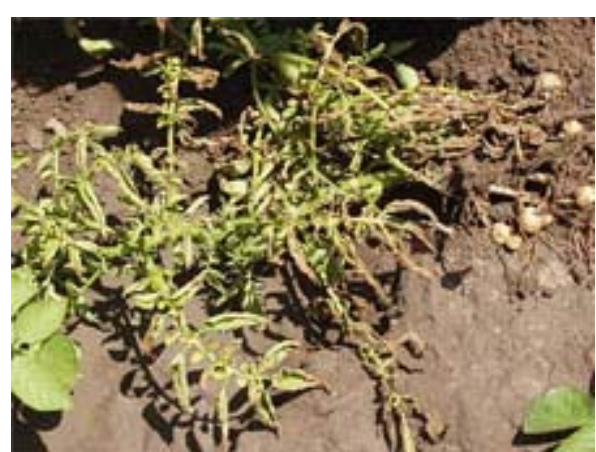

Fig. 3. Severe chlorosis and scorch of zebra chip infected plant.

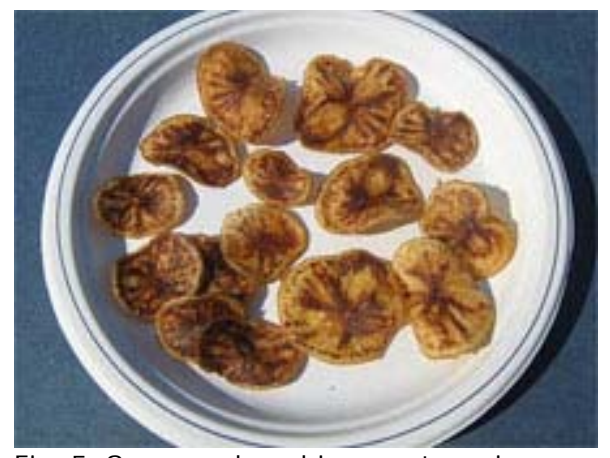

Fig. 5. Severe zebra chip symptoms in processed chips. 
By 2007, there were reports of similar symptoms being observed in potatoes grown in Nebraska, Colorado, Kansas, New Mexico, Arizona, Nevada, and California (21). Also, in 2006-2007, potatoes grown in Honduras were observed that had foliar and tuber symptoms resembling those of zebra chip. Some fields were severely affected and were total losses because of unmarketable tubers (Fig. 6) (26).

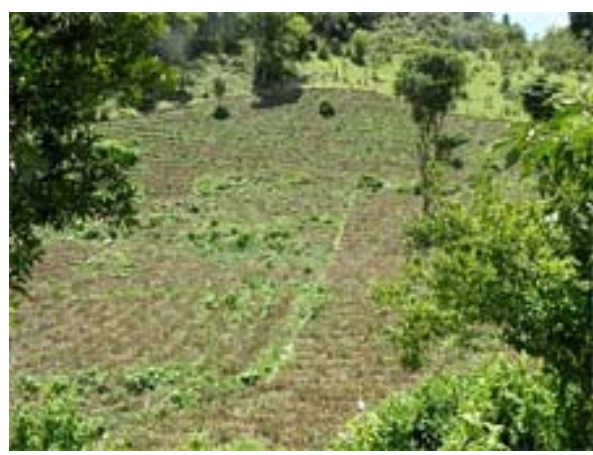

Fig. 6. Potato field in Honduras during 2009 that is severely affected by zebra chip disease. This field experienced $100 \%$ infection early in the season and was a total loss.

In the summer of 2005, Crosslin and Munyaneza were contacted by personnel at FritoLay, Inc. who were seeing the symptoms described above in tubers grown in their Texas production areas. Because the foliar symptoms resembled those caused by phytoplasmas, symptomatic shoot, and tuber samples were tested by conventional nested PCR for phytoplasmas (20) and all were negative. At about the same time, samples from Texas were sent to other plant pathology laboratories and similarly tested for phytoplasmas, with the same negative result (31). These results indicated that ZC differed from a similar potato disease, "purple top," that was associated with a phytoplasma infection occurring in Texas and Nebraska at about the same time (29). Numerous additional tests for Tomato spotted wilt virus, Tobacco rattle virus, Alfalfa mosaic virus, Potato leafroll virus, Potato mop top virus, Potato virus Y, Xylella fastidiosa, and Serratia marescens were all negative (25).

In conjunction with the molecular tests described above, in the fall of 2005 and winter of 2006 symptomatic potato shoots were tip-grafted onto various potato cultivars to determine if there was some infectious agent that could be transmitted to healthy potato. Approximately 4 weeks after grafting, most of the recipient plants began to display symptoms similar to the original plants (Fig. 7) and tubers harvested from the grafted plants showed the characteristic discoloration (5) (Fig. 8). Similar grafting results were obtained by other laboratories (31). These results strongly suggested that a pathogen was involved in the ZC disease, although none had been identified.

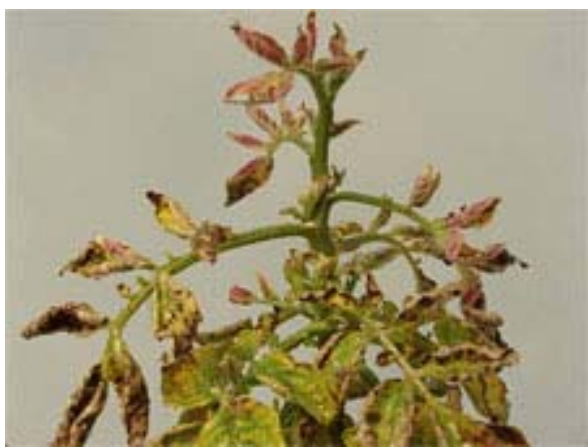

Fig. 7. Zebra chip symptoms in potato cv. "Atlantic" 60 days after grafting with a zebra chip symptomatic shoot.

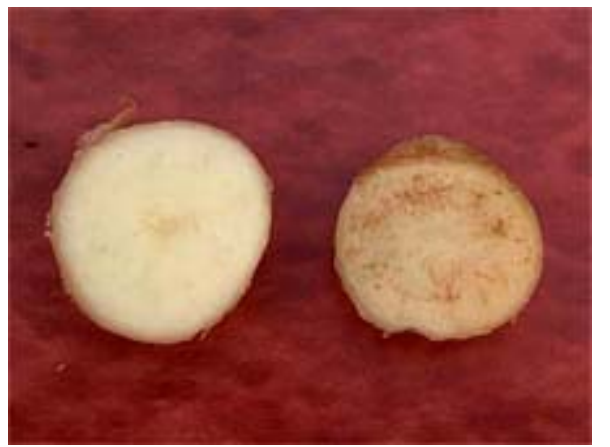

Fig. 8. Zebra chip symptoms in freshly cut tuber from plant grafted with ZC symptomatic shoot (right). Tuber from a plant grafted with a healthy potato shoot is on the left. 


\section{Association of the Potato Psyllid with the Disease}

Since the symptoms of ZC resembled those of a phytoplasma infection, potential vector insects were collected from affected fields in south Texas beginning in 2005-2006. However, few leafhoppers, the primary vectors of phytoplasmas, were observed. The predominant insect collected at these sites was identified as the potato-tomato psyllid, Bactericera cockerelli (Sulc) (10). The potato psyllid has piercing-sucking mouthparts and the adult is about the same size as a winged aphid (Fig. 9) (Additional photographs of the potato psyllid can be viewed at InsectImages.org.) Many psyllids were tested by PCR for phytoplasmas, usually in groups of five, and only a small percentage of these were positive, providing evidence that the psyllid was not an important vector of phytoplasmas $(20,21)$. Studies were subsequently undertaken where psyllids were introduced into cages containing potato plants and plants were observed for production of ZC symptoms. Most of the infested plants developed ZC foliar symptoms and the tubers also showed the characteristic symptoms $(20,21)$. Later, more extensive cage trials with psyllids derived from numerous sources gave similar results (Fig. 10). However, infestation with psyllids from some sources did not result in ZC-symptomatic plants (18). This result suggested that some populations of psyllids could be free of the as-yet unidentified pathogen. Some "yellows" type symptoms, however, were produced in plants that were infested with populations of psyllids that did not result in production of ZC symptoms. This could be postulated to be due to psyllid feeding itself, as the presence of a toxin associated with the psyllid has been proposed for many decades $(3,7,27)$. Also, psyllid feeding by itself might cause some necrotic symptoms in tubers $(28,33)$.

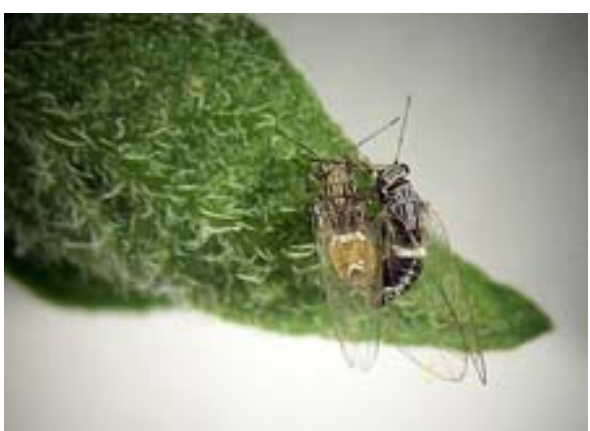

Fig. 9. Adult potato psyllids. Photo courtesy Jeremy Buchman.

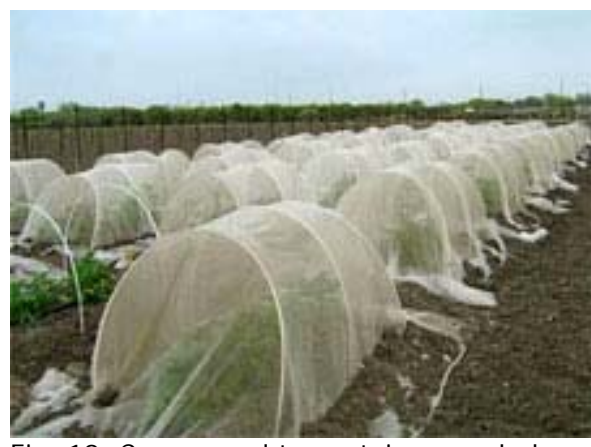

Fig. 10. Cages used to contain or exclude psyllids, Weslaco, TX, 2008.

\section{I dentification of the Putative Causal Agent, Geographic}

Distribution, and Additional Hosts

In J anuary of 2008, scientists at the Plant Health and Environment

Laboratory, MAF Biosecurity New Zealand, began an investigation to determine the etiology of a new disease of glasshouse-grown tomato (Solanum lycopersicum) and pepper (Capsicum annuum) crops (14), unaware of the connection with ZC. All diseases known to affect tomato and pepper were ruled out, including pathogenic fungi, cultureable bacteria, viruses, viroids, and phytoplasmas. The symptoms looked very similar to those caused by phytoplasmas and therefore attempts to find another kind of bacterium-like organism were pursued. The first breakthrough came in April 2008 when transmission electron microscopy of thin sections of leaf tissue from symptomatic tomato plants revealed the presence of phloem-limited bacteriumlike organisms. Various PCR primers were used in different combinations to amplify putative prokaryotic DNA extracted from both healthy and symptomatic plants. In May 2008, one of the primer combinations produced a unique PCR amplicon from symptomatic plants only. Sequence analysis of this fragment revealed that it shared high identity with bacteria related to the Candidatus Liberibacter species, the causal agents of citrus greening (huanglongbing) disease. On $4 \mathrm{~J}$ une 2008, MAF Biosecurity issued a press release on this new bacterium. The possible link between the tomato and pepper diseases and ZC became apparent when a New Zealand potato breeder contacted MAF 
Biosecurity New Zealand soon after their press release. The grower reported unusual foliar and tuber symptoms and high numbers of the potato psyllid were observed in his potato crops that season. Tubers collected from the potato breeder subsequently tested positive for the liberibacter (13). Over the next year (J une 2008-J uly 2009), various researchers reported detection of the liberibacter in potatoes showing ZC symptoms in the United States and New Zealand $(1,14,17,22,31)$, supporting the argument that the liberibacter is associated with the ZC disease. Workers in New Zealand named the new liberibacter species "Candidatus Liberibacter solanacearum," the epithet referring to the family of plant hosts from which the bacterium has been identified (16).

Meanwhile, in the spring and summer of 2008, Allison Hansen, a doctoral student in the Department of Entomology, University of California at Riverside, detected the Ca. Liberibacter through her research on symbionts of the potato psyllid. Universal prokaryote rRNA primers were initially used to amplify DNA from a "symbiont" from potato psyllids. The resulting $2.6 \mathrm{kbp}$ DNA fragment was sequenced, enabling the design of specific primers to amplify and sequence smaller fragments of this region. These researchers tentatively designated the bacterium "Candidatus Liberibacter psyllaurous" and it was so-named for its association with psyllid yellows (12). Recent evidence, however, suggests that $\mathrm{ZC}$ results when the Ca. Liberibacter is transmitted by the potato psyllid to a suitable host and that psyllid yellows results from the feeding of liberibacterfree psyllids (32).

Similar to the research efforts on potato and tomato diseases in New Zealand and at UC Riverside described above, in the summer of 2006 tomato plants in a large commercial greenhouse facility in northern Arizona exhibited dark green veins, interveinal chlorosis, foliar curling, and shortened internodes. Research failed to reveal the presence of well-studied DNA or RNA viruses, leading to the hypothesis that a phytoplasma might be involved. A second puzzling observation was that the major insect infesting these tomato plants was the potato psyllid. Initial PCR tests using various primer pairs designed to amplify the 16S rRNA of phytoplasmas failed to yield a specific product from symptomatic, psyllid-infested tomato plants. Discussions with a number of colleagues resulted in the application of a new PCR primer set for phytoplasma detection. Using these primers, followed by cloning and DNA sequencing of PCR products, three of 15 amplicons from symptomatic tomatoes had the closest match to the 16S rDNA sequence for the three recognized "Candidatus Liberibacter" bacterial species in the citrus greening complex Ca. L. asiaticus, Ca. L. africanus, and Ca. L. americanus. Redesign of PCR primers that were based on the Ca. L. asiaticus-like sequences resulted in amplification of a fragment of the 16S rDNA of the Ca. Liberibacter-like bacterium detected in the tomato samples. PCR also confirmed presence of the bacterium in potato psyllids reared on laboratory tomato plants initially established from cuttings of symptomatic plants from the greenhouse in northern Arizona, confirming psyllid transmission (2). Additional PCR assays confirmed the presence of the bacterium in potato samples from Honduras collected in 2006-2007 that exhibited foliar yellowing and internal browning of the tubers, which are consistent with the zebra chip disease (26).

This ZC-associated bacterium, if indeed only one "species" is involved, has also been detected in other solanaceous plants in New Zealand including tamarillo (Solanum betaceum) and cape goose berry (Physalis peruviana) [(15), and Wikipedia link, below]. The bacterium was also recently reported infecting tomatoes and peppers in Mexico $(23,24)$. Additionally, we have successfully transmitted our ZC liberibacter to Datura spp. by grafting (unpublished). These results suggest that numerous solanaceous plants are potential, if not natural, hosts of the bacterium due to the feeding preference of the potato psyllid.

Various research groups have cloned and sequenced portions of the $16 \mathrm{~S}$ and 23S ribosomal RNA genes (rDNA) and some of the ribosomal protein genes of the liberibacter. Sequence analysis suggests that "psyllaurous" and "solanacearum" are the same bacterium, however a few minor differences in their sequences have been reported, suggesting the occurrence of more than one 
strain of this bacterium $(16,31,34)$. Subsequent studies to examine additional regions of the genome of the ZC Ca. Liberibacter will increase our understanding of the extent of diversity within this bacterium. What is now clear from the sequence information is that the ZC bacterium, a member of the alphaproteobacteria, is most closely related to "Candidatus Liberibacter asiaticus," "Candidatus Liberibacter africanus," and "Candidatus Liberibacter americanus," bacteria that are associated with the serious citrus greening (huanglongbing) disease in Asia, Africa, and the Americas (12,14,17,34).

Evidence suggests that the Ca. Liberibacter from potato and tomato is naturally transmitted both horizontally from plant to plant by the psyllid vector and vertically (transovarially) in the psyllid population (12). This capability of the bacterium has broad epidemiological implications since an "overwintering host" for the bacterium may not be needed to sustain the pathogen. Rather, an established population of the psyllid host would maintain the pathogen, at least at some level, which would be subsequently transmitted to susceptible crops the following season, thereby serving as a primary source of inoculum for acquisition by bacteria-free psyllids.

\section{Perspectives and Future Outlook}

From the discussion above, it is apparent that the Ca. Liberibacter and the potato zebra chip disease and the diseases of tomatoes and peppers would appear to be relatively "new arrivals," at least in the United States and New Zealand. This raises the questions of its origins and what it could potentially mean to potato, tomato, and pepper production in the United States, Mexico, Central America, New Zealand, and wherever it emerges next. The effect of the Ca. Liberibacter on a long-lived tree crop such as tamarillo has already been obvious with death of the tree occurring within months after appearance of the first symptoms. Indeed, the apparently rapid spread of the disease in the United States and the introduction into New Zealand (the psyllid was first reported in 2006) would suggest that this insect-pathogen complex has the potential for rapid spread with devastating consequences. In the Pacific Northwest, where nearly half of US potatoes are produced, potato psyllids are present (19). However, they "arrive" in late July or August, which is near the end of the potato-growing season in Washington, Oregon, and Idaho. The origin of these migrating psyllids has not been determined (19). The ZC Ca. Liberibacter was recently confirmed in California (4) and poses a significant threat in that area because of the widespread occurrence of the psyllid in that region. The potato psyllid is known to occur in most of the western United States and parts of Canada and it may be just a question of how late in the season the insect arrives each year. Studies in Texas and Washington suggest that earlier infection in potato result in more severe symptoms compared to infections that occur later in the season. If plants are infected late enough in the season the effects are minimized. However, should the psyllid be able to overwinter as either eggs or adults in milder climates in other potato growing regions of the United States or other countries, then the impact could be severe since the crop would be infested at an early growth stage.

Currently, growers of chipping potatoes in Texas are vigorously scouting for the potato psyllid using yellow sticky traps and/ or sweep nets. The psyllid is being targeted with aggressive insecticide programs and this has greatly reduced the damage caused by ZC in this region compared to 2004-2005 $(8,9)$.

Ultimately, the psyllid may develop resistance to some of the compounds being recommended for control and this may limit control options $(8,9)$. University of California guidelines for management of the potato psyllid can be found at UC Davis website. Proper insecticide rates, accurate timing, suitable number of applications, and rotation of active ingredients are essential components of a psyllid control program and will help to prevent development of insecticide resistance.

In 2009, thousands of psyllids collected in Texas, Kansas, and Nebraska were tested for Ca. Liberibacter individually or in pairs. Only about $2 \%$ were positive for the bacterium (Crosslin, unpublished). Reports from these areas also suggest that the ZC incidence was relatively low in these areas. Additional 
testing in 2010 may improve our understanding of the relationship between incidence of the pathogen in the psyllid and the incidence of disease in the field.

The New Zealand and Arizona experience with psyllids transmitting the bacterium to greenhouse tomatoes and peppers underscores the potential of this psyllid-bacterial pathogen complex to cause economic damage outside of a field setting. Quarantine considerations have also emerged, since some countries are now requiring specific testing for liberibacter prior to allowing shipment of potatoes to those countries (Crosslin, unpublished). Furthermore, Australia banned the importation of fresh tomato and pepper from New Zealand for 6 months. When international trade resumed, additional quarantine requirements had been put in place by Biosecurity Australia where growers need to ensure that crops for export have been produced in areas free from the psyllid or the exported produce must be free of the psyllid. The Australian market for fresh tamarillos from New Zealand was temporarily closed but has recently reopened. Although the exact method by which the psyllid and liberibacter entered New Zealand is unknown, one plausible scenario would be as psyllid eggs on plant material. The potato psyllid has been found in greenhouses in Arizona and New Zealand, as described above, and also in greenhouses in Ontario, Canada. These findings would suggest that psyllidinfested tomato (or other host) plantings in commercial greenhouses could serve as important overwintering sources of the psyllid and bacterial pathogen for subsequent migration to other crops.

Information about the potato psyllid and its association with Ca. Liberibacter is beginning to accumulate, but many important details about the epidemiology and of pathogen-vector interactions are scanty or lacking entirely. It is expected that during the next few years new information will aid efforts to eliminate "striped potatoes" and the apparently related diseases of tomato, pepper, and other important solanaceous crops.

\section{Acknowledgments}

Partial funding for this research was provided by Frito-Lay, Inc. and the National Potato Council. Special thanks go to cooperator J ohn Goolsby for the psyllid collections. Technical assistance was provided by Venkat Sengoda, J eremy Buchman, Richard Delorme, and Launa Hamlin.

\section{Literature Cited}

1. Abad, J . A., Bandla, M., French-Monar, R. D., Liefting, L. W., and Clover, G. R. G. 2009. First report of the detection of 'Candidatus Liberibacter' species in zebra chip disease-infected potato plants in the United States. Plant Dis. 93:108.

2. Brown, J . K., Rehman, M., Rogan, D., Martin, R. R., and Idris, A. M. 2010. First report of "Candidatus Liberibacter psyllaurous" (synonym "Ca. L. solanacearum") associated with 'tomato vein-greening' and 'tomato psyllid yellows' diseases in commercial greenhouses in Arizona. Plant Dis. 94:376.

3. Cranshaw, W. W. 2001. Psyllid yellows. Pages 73-74 in: Compendium of Potato Diseases, 2nd Edn. W. R. Stevenson, R. Loria, G. D. Franc, and D. P. Weingartner, eds. American Phytopathological Society, St. Paul, MN.

4. Crosslin, J . M. and Bester, G. 2009. First report of Candidatus Liberibacter psyllaurous in zebra chip symptomatic potatoes from California. Plant Dis. 93:551.

5. Crosslin, J . M. and Munyaneza, J. E. 2009. Evidence that the zebra chip disease and the putative causal agent can be maintained in potatoes by grafting and in vitro. Am. J . Pot. Res. 86:183-187.

6. De Boer, S. H., Secor, G., Li, X., Gourley, J., Ross, P., and Rivera, V. 2007. Preliminary characterization of the etiologic agent causing zebra chip symptoms in potato. Online. Proc. of EAPR Pathol. Section Seminar, 2-6 J uly 2007, Hattula, Finland. Agrifood Research Working Paper 142, MTT Agrifood Res. Finland, Info. Mgt., J okioinen, Finland.

7. Eyer, J. R., and Crawford, R. F. 1933. Observations on the feeding habits of the potato psyllid (Paratrioza cockerelli Sulc) and the pathological history of the "psyllid yellows" which it produces. J. Econ. Entomol. 26:846-850. 
8. Gharalari, A. H., Nansen, C., Lawson, D. S., Gilley, J ., Munyaneza, J. E., and Vaughn, K. 2009. Knockdown mortality, repellency, and residual effects of insecticides for control of adult Bactericera cockerelli (Hemiptera: Psyllidae). J . Econ. Entomol. 102:1032-1038.

9. Goolsby, J . A., Adamcyk, J., Bextine, B., Lin, D., Munyaneza, J. E., and Bester, G. 2007a. Development of an IPM program for management of the potato psyllid to reduce incidence of zebra chip disorder in potatoes. Subtrop. Plant Sci. 59:85-94.

10. Goolsby, J . A., Bextine, B., Munyaneza, J . E., Setamou, M. Adamczyk, J ., and Bester, G. 2007. Seasonal abundance of sharpshooters, leafhoppers, and psyllids associated with potatoes affected by zebra chip disorder. Subtrop. Plant Sci. 58:1523.

11. Gudmestad, N. C., and Secor, G. A. 2007. Zebra chip: A new disease of potato. Nebraska Potato Eyes 19:1-4.

12. Hansen, A. K., Trumble, J . T., Stouthamer, R., and Paine, T. D. 2008. A new huanglongbing species, "Candidatus Liberibacter psyllaurous," found to infect tomato and potato, is vectored by the psyllid Bactericera cockerelli (Sulc). App. Env. Micro. 74:5862-5865.

13. Liefting, L. W., Perez-Egusquiza, Z. C., Clover, G. R. G., and Anderson, J . A. D. 2008. A new 'Candidatus Liberibacter' species in Solanum tuberosum in New Zealand. Plant Dis. 92:1474.

14. Liefting, L. W., Sutherland, P. W., Ward, L. I., Paice, K. L., Weir, B. S., and Clover, G. R. G. 2009. A new 'Candidatus Liberibacter' species associated with diseases of Solanaceous crops. Plant Dis. 93:208-214.

15. Liefting, L. W., Ward, L. I., Shiller, J. B., and Clover, G. R. G. 2008. A new 'Candidatus Liberibacter' species in Solanum betaceum (tamarillo) and Physalis periviana (cape gooseberry) in New Zealand. Plant Dis. 92:1588.

16. Liefting, L. W., Weir, B. S., Pennycook, S. R., and Clover, G. R. G. 2008. 'Candidatus Liberibacter solanacearum', a liberibacter associated with plants in the family Solanaceae. Int. J . Syst. Evol. Microbiol. 59:2274-2276.

17. Lin, H., Doddapaneni, H., Munyaneza, J . E., Civerolo, E. L., Sengoda, V. G., Buchman, J. L., and Stenger, D. C. 2009. Molecular characterization and phylogenetic analysis of 16S rRNA from a new "Candidatus Liberibacter" strain associated with zebra chip disease of potato (Solanum tuberosum L.) and the potato psyllid (Bactericera cockerelli Sulc). J . Plant Path. 91:215-219.

18. Munyaneza, J. E., Buchman, J . L., Upton, J. E., Goolsby, J . A., Crosslin, J . M., Bester, G., Miles, G. P., and Sengoda, V. G. 2008. Impact of different potato psyllid populations on zebra chip disease incidence, severity, and potato yield. Subtrop. Plant Sci. 60:27-37.

19. Munyaneza, J. E., Crosslin, J. M., and Buchman, J. L. 2009. Seasonal occurrence and abundance of the potato psyllid, Bactericera cockerelli, in south central Washington. Am. J. Pot. Res. 86:513-518.

20. Munyaneza, J. E., Crosslin, J. M., and Upton, J. E. 2007. Association of Bactericera cockerelli (Homoptera: Psyllidae) with "zebra chip", a new potato disease in southwestern United States and Mexico. J . Econ. Entomol. 100:656663.

21. Munyaneza, J. E., Goolsby, J . A., Crosslin, J . M., and Upton, J . E. 2007. Further evidence that zebra chip potato disease in the lower Rio Grande Valley of Texas is associated with Bactericera cockerelli. Subtrop. Plant Sci. 59:30-37.

22. Munyaneza, J . E., Sengoda, V. G., Crosslin, J . M., Dela Rosa-Lozano, G., and Sanchez, A. 2009. First report of 'Candidatus Liberibacter psyllaurous' in potato tubers with zebra chip disease in Mexico. Plant Dis. 93:552.

23. Munyaneza, J . E., Sengoda, V. G., Crosslin, J . M., Garzon-Tiznado, J . A., and Cardenas-Valenzuela, O. G. 2009. First report of 'Candidatus Liberibacter solanacearum' in tomato plants in Mexico. Plant Dis. 93:1076

24. Munyaneza, J . E., Sengoda, V. G., Crosslin, J. M., Garzon-Tiznado, J . A., and Cardenas-Valenzuela, O. G. 2009. First report of 'Candidatus Liberibacter solanacearum' in pepper in Mexico. Plant Dis. 93:1076.

25. Navarre, D. A., Shakya, R., Holden, J., and Crosslin, J. M. 2009. LC-MS analysis of phenolic compounds in tubers showing zebra chip symptoms. Am. J. Pot. Res. 86:88-95.

26. Rehman, M., Melgar, J. C., Rivera-C., J . M., Idris, A. M., and Brown, J. K. 2010. First report of "Candidatus Liberibacter psyllaurous" or Ca. Liberibacter solanacearum" associated with severe foliar chlorosis, curling, and necrosis, and tuber discoloration of potato plants in Honduras. Plant Dis. 94:376. 
27. Richards, B. L. 1928. A new and destructive disease of the potato in Utah and its relation to the potato psylla. (Abstr.) Phytopathology 18:140-141.

28. Sanford, G. B. 1952. Phloem necrosis of potato tubers associated with infestation of vines by Paratrioza cockerelli Sulc. Sci. Agric. 32:433-439.

29. Secor, G. A., Lee, I.-M., Bottner, K. D., Rivera-Varas, V., and Gudmestad, N. C. 2006. First report of a defect of processing potatoes in Texas and Nebraska associated with a new phytoplasma. Plant Dis. 90:377.

30. Secor, G. A., and Rivera-Varas, V. V. 2004. Emerging diseases of cultivated potato and their impact on Latin America. Rev. Latinoamericana Papa (Suppl.) 1:1-8.

31. Secor, G. A., Rivera, V. V., Abad, J . A., Lee, I.-M., Clover, G. R .G., Liefting, L. W., $\mathrm{Li}, \mathrm{X}$., and De Boer, S. H. 2009. Association of 'Candidatus Liberibacter solanacearum' with zebra chip disease of potato established by graft and psyllid transmission, electron microscopy, and PCR. Plant Dis. 93:574-583.

32. Sengoda, V. G., Munyaneza, J . E., Crosslin, J . M., Buchman, J . L., and Pappu, H. R. 2010. Phenotypic and etiological differences between psyllid yellows and zebra chip diseases of potato. Am. J . Pot. Res. 87:41-49.

33. Snyder, W. C., Thomas, H. E., and Fairchild, S. J . 1946. A type of internal necrosis of the potato tuber caused by psyllids. Phytopathology 36:480-481.

34. Wen, A., Mallik, I., Alvarado, V. Y., Pasche, J. S., Wang, X., Li, W., Levy, L., Lin, H., Scholthof, H. B., Mirkov, T. E., Rush, C. M., and Gudmestad, N. C. 2009. Detection, distribution, and genetic variability of 'Candidatus Liberibacter' species associated with zebra complex disease of potato in North America. Plant Dis. 93:1102-1115.

\section{Related Online Resources}

Wikipedia: zebra chip

MAF Biosecurity New Zealand: Association of the liberibacter with diseases of tomato and pepper in New Zealand

Potato Product Group of Horticulture New Zealand: Information on the zebra chip disease on potatoes focused on the New Zealand experience

Texas A \& M University: information on zebra chip

European Plant Protection Organization (EPPO): information on zebra chip liberibacter 